\title{
Aspiration in injections: should we continue or abandon the
}

\section{practice? [version 1; peer review: 1 approved, 1 approved with}

\section{reservations]}

\author{
Yasir Sepah1,2, Lubna Samad1,3, Arshad Altaf(id,5, Nithya Rajagopalan², \\ Aamir Javed Khan ${ }^{1,3}$ \\ ${ }^{1}$ Centre for Injection Safety Pakistan, Interactive Research \& Development, Karachi, Pakistan \\ 2University of Nebraska Medical Center, Omaha, NE, USA \\ ${ }^{3}$ The Indus Hospital, Karachi, 75190, Pakistan \\ ${ }^{4}$ Bloomberg School of Public Health, Johns Hopkins University, Baitmore, MD, USA \\ ${ }^{5}$ Canada-Pakistan HIV/AIDS Surveillance Project, Sindh AIDS Control Programme, Karachi, Pakistan
}

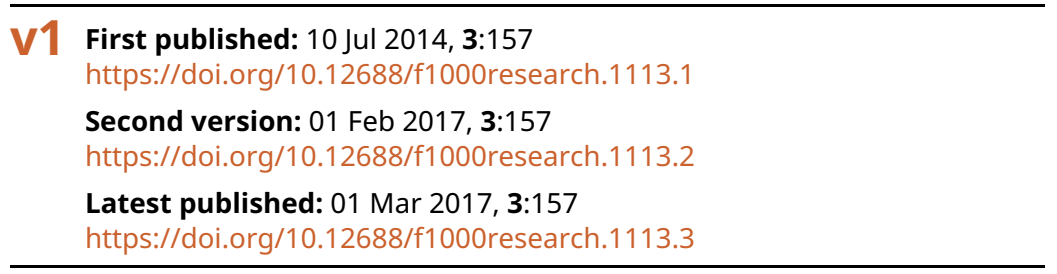

\section{Abstract}

Aspiration during any kind of injection is meant to ensure that the needle tip is at the desired location during this blind procedure. While aspiration appears to be a simple procedure, it has generated a lot of controversy concerning the perceived benefits and indications.

Advocates and opponents of aspiration both make logically sound claims. However, due to scarcity of available data, there is no evidence that this procedure is truly beneficial or unwarranted. Keeping in view the huge number of injections given worldwide, it is important that we draw attention to key questions regarding aspiration that, up till now, remain unanswered. In this review, we have attempted to gather and present literature on aspiration both from published and nonpublished sources in order to provide not only an exhaustive review of the subject, but also a starting point for further studies on more specific areas requiring clarification. A literature review was conducted using the US National Institute of Health's PubMed service (including Medline), Google Scholar and Scopus. Guidelines provided by the World Health Organization, Safe Injection Global Network, International Council of Nursing, Center for Disease Control, US Federal Drug Agency, UK National Health Services, British Medical Association, Europe Nursing and Midwifery Council, Public Health Agency Canada, Pakistan Medical Association and International Organization of Standardization recommendations 7886 parts 1-4 for sterile hypodermics were reviewed for relevant information. In addition, curricula of several medical/-nursing schools from India, Nigeria and Pakistan, the US pharmacopeia Data from the WHO

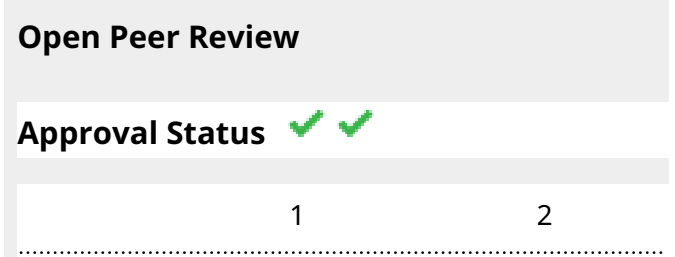

version 3

(revision)

01 Mar 2017

version 2

(revision)

01 Feb 2017

version 1

10 Jul 2014

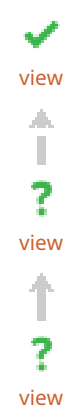

1. Cees Smit Sibinga ID, IQM Consulting for International Development of Quality Management in Transfusion Medicine, Zuidhorn, The Netherlands

2. Ankit Balani, Yashoda Hospitals,

Secunderabad, India

Sandhya Sarjare, Yashoda Hospital,

Secunderabad, India

Any reports and responses or comments on the article can be found at the end of the article. 
Program for International Drug Monitoring network in regard to adverse events as a result of not aspirating prior to injection delivery were reviewed. Curricula of selected major medical/nursing schools in India, Nigeria and Pakistan, national therapeutic formularies, product inserts of most commonly used drugs and other possible sources of information regarding aspiration and injections were consulted as well.

Corresponding authors: Yasir Sepah (yjs@oirrc.net), Lubna Samad (Isamad@jhsph.edu)

Competing interests: No competing interests were disclosed.

Grant information: This literature review was funded by Star Syringe Ltd UK. All decisions regarding the content of the manuscript and final responsibility for submission of the manuscript belong to the authors.

Copyright: $@ 2014$ Sepah Y et al. This is an open access article distributed under the terms of the Creative Commons Attribution License, which permits unrestricted use, distribution, and reproduction in any medium, provided the original work is properly cited. Data associated with the article are available under the terms of the Creative Commons Zero "No rights reserved" data waiver (CCO 1.0 Public domain dedication).

How to cite this article: Sepah Y, Samad L, Altaf A et al. Aspiration in injections: should we continue or abandon the practice? [version 1; peer review: 1 approved, 1 approved with reservations] F1000Research 2014, 3:157

https://doi.org/10.12688/f1000research.1113.1

First published: 10 Jul 2014, 3:157 https://doi.org/10.12688/f1000research.1113.1 


\section{Introduction}

An injection is defined by the World Health Organization (WHO) as parenteral administration of medication through a skin puncture via a syringe, while aspiration is defined as the pulling back of the plunger of a syringe (for 5-10 seconds) prior to injecting medicine $\mathrm{e}^{1-4}$. Aspiration is most commonly performed during an intramuscular [IM] or subcutaneous [SC] injection, and is meant to ensure that the needle tip is located at the desired site, and has not accidentally punctured a blood vessel.

Despite the growing wealth of medical knowledge in recent decades, the simple procedure of aspiration is still generating much controversy concerning its perceived benefits and indications ${ }^{5}$. Advocates of aspiration contend that it is a technically easy maneuver that is rapidly performed and well tolerated by patients with no increase in costs incurred. However, due to a paucity of available data, there is no evidence that this procedure is essential or truly beneficial. This issue has been widely debated with specific regard to vaccination; there are no studies that have assessed the need for aspiration prior to IM injection of vaccines in relation to vaccine safety. The widespread use of auto-disable (AD) syringes - most of which are not designed to aspirate ${ }^{6}-$ has not been linked to adverse effects due to the elimination of the aspiration procedure prior to injection of vaccines ${ }^{7}$. This finding has intensified the debate and raised doubts over the necessity of aspiration in non-vaccine medication administration as well.

Conventional syringes are also used to aspirate materials other than blood - synovial fluid, amniotic fluid, cells (via fine needle cytology), pericardial fluid, peritoneal fluid and cerebrospinal fluid (CSF) are examples ${ }^{8-19}$. This wide spectrum of applications for conventional syringes is all the more interesting in view of the fact that although used for both aspiration and injection, the syringe is actually designed only for injection ${ }^{20}$. A number of studies have concluded that a conventional syringe is a poorly controlled and non-ergonomic device during aspiration ${ }^{21,22}$. Possible lack of precision may result in local trauma and pain, prolonged procedure time, failed or incomplete procedures, accidental puncture of blood vessels or nerve bundles, poor sample retrieval and delayed diagnosis ${ }^{23-33}$. The ingrained use of the conventional syringe for injection and aspiration is to a large extent attributable to its low cost, widespread availability and lack of an effective alternative ${ }^{21}$.

The huge volume of injections being given worldwide - an estimated 16 billion injections per year are administered in the developing and transitional countries alone ${ }^{34}$ - necessitates that this aspect of injection technique be given due attention. This review aims to collate Englishlanguage literature on aspiration from all published and non-published sources in order to provide an overview on the subject. In particular, this review aims to highlight areas of debate and draw attention to key questions that remain unanswered, thus providing a starting point for controlled studies on specific areas requiring clarification.

\section{Methodology}

Literature review

An literature review was conducted using the US National Institute of Health's PubMed service (including Medline), archives of SIGNpost, the weekly electronic newsletter of the World Health Organization's (WHO) Safe Injection Global Network (SIGN), and
International Organization of Standardization (ISO) recommendations 7886 parts $1-4$ for sterile hypodermics. Clarification on points of debate was sought by direct communication with ISO. Google Scholar was also used to search for relevant information. Relevant search terms for PubMed and Google Scholar literature searches are listed below.

Guidelines from the WHO, International Council of Nursing (ICN), US Center for Disease Control (CDC), US Federal Drug Agency (FDA), UK National Health Service (NHS), British Medical Association, UK Nursing and Midwifery Council (NMC), and Australian Nursing and Midwifery Accreditation Council, Public Health Agency Canada and the Pakistan Medical Association (PMA) were extensively searched for information. Data from the WHO Program for International Drug Monitoring network in regard to adverse events as a result of not aspirating prior to injection delivery were reviewed. Curricula of selected major medical/nursing schools in India, Nigeria and Pakistan were also reviewed for relevant information to document the inclusion (or otherwise) of aspiration in teaching guidelines for injection technique.

National therapeutic manuals and formularies such as British National Formulary (BNF), European Pharmacopeia (EP), United States Pharmacopeia (USP) and Pakistan Pharma Guide (PPG) were also consulted for information regarding aspiration before injection. Product inserts for all injectable drugs on the WHO Essential Drug List (EDL) were collected to determine if the manufacturer had provided instructions on aspiration prior to injecting the drug. These product inserts were collected from local pharmacies and the international manufacturers for each drug. Drug inserts from multinationals were acquired either directly from their websites or from other online resources including the Drug Index (www.Rxlist.com), Australian Prescription Products Guide (www.appgonline.com.au/ default.asp) and from (http://www.rxmed.com/).

\section{Results}

Our review was conducted between March 2008 and March 2014. Table 1 summarizes the resources searched.

\section{Literature review findings}

Published literature on injection technique advises aspiration before injecting a drug through different routes, i.e. $\mathrm{IM}^{35}$, intravascular $(\mathrm{IV})^{36}$ or $\mathrm{SC}^{37}$. However, it is important to note that emphasis has been placed on negative pressure being applied for 5-10 seconds for aspiration to be of benefit ${ }^{1,3,4}$. During the administration of an IV injection, the presence of "flashback" (return of blood into the syringe or cannula) is a passive process and active aspiration is usually not necessitated; hence, this particular route of administration has not been emphasized in the review below.

IM injections. Aspiration prior to injection of medication through the IM route remains a part of most guidelines ${ }^{4,35,38-40}$. Nursing curricula and guidelines $\mathrm{s}^{4,38,39}$ clearly recommend aspiration as an essential step in IM injection technique. Guidelines originating in the UK recommend aspiration prior to IM injection of medications ${ }^{35}$, as well as specifically as part of the Z-track technique of administering IM injections. Training curricula for community health workers in Nigeria recommend aspiration prior to IM, SC and intradermal [ID] injections $\mathrm{s}^{40}$. 
Table 1. Description of peer items reviewed with numbers reviewed.

\begin{tabular}{|c|c|c|}
\hline Items & $\begin{array}{l}\text { Number of Items } \\
\text { Reviewed }\end{array}$ & Description \\
\hline Articles & 78 & $\begin{array}{l}\text { PubMed } \\
\text { Google Scholar }\end{array}$ \\
\hline Non-indexed publications & 90 & $\begin{array}{l}\text { Websites of WHO, CDC, ICN, Canadian Public } \\
\text { Health Agency, UNICEF, pharmaceutical companies } \\
\text { SIGN-Post } \\
\text { Internet Drug Index } \\
\text { Australian Prescription Products Guide } \\
\text { Rxmed.com } \\
\text { Wikipedia }\end{array}$ \\
\hline International guidelines & 4 & $\begin{array}{l}\text { WHO } \\
\text { ICN } \\
\text { NMC Europe } \\
\text { ISO } 7886 \text { (part 1-4) }\end{array}$ \\
\hline National Guidelines & 5 & $\begin{array}{l}\text { NHS UK } \\
\text { NMC UK } \\
\text { CDC USA } \\
\text { FDA USA } \\
\text { PHA Canada }\end{array}$ \\
\hline $\begin{array}{l}\text { Medical and Nursing } \\
\text { Curriculum }\end{array}$ & 4 & $\begin{array}{l}\text { Aga Khan University School of Medicine, Pakistan } \\
\text { National Nigerian Nursing School } \\
\text { INCLEN }\end{array}$ \\
\hline Formularies & 3 & $\begin{array}{l}\text { BNF UK } \\
\text { European Pharmacopeia } \\
\text { US Pharmacopeia } \\
\text { Pakistan Pharma guide }\end{array}$ \\
\hline $\begin{array}{l}\text { WHO Essential Drug List Product } \\
\text { Inserts for Injectable Drugs }\end{array}$ & $\begin{array}{l}155 \text { Injectable listed } \\
104 \text { reviewed }\end{array}$ & \\
\hline
\end{tabular}

SC injections. It is apparent that there are opposing schools of thought when it comes to aspiration prior to SC injections. There are those that insist that aspiration should continue to be part of SC injection techniques for medication administration, and those who are convinced that aspiration is not necessary and has no real advantage; in fact, several disadvantages may be attributed to this step.

Some nursing curricula do not include aspiration as part of the recommended technique ${ }^{38}$ for SC injection. One nursing guideline highlights the debate existing over aspiration prior to a SC injection, concluding that while the likelihood of piercing a vessel is slim, local guidelines should be followed in determining individual practices. Others recommend routine aspiration prior to injection of medications through the $\mathrm{SC}$ route ${ }^{42}$.

The WHO/ICN ${ }^{43}$ combined guidelines do not mention aspiration. Similarly, the WHO/SIGN document ${ }^{44}$ "A Guide For Supervising Injections" makes no recommendations related to aspiration. Both documents are primarily concerned with infection control practices in relation to injection administration, overlooking aspiration entirely.

A recent debate in relation to SC injection of immunotherapy has highlighted this controversy. Waibel recommended that aspiration before SC injection of immunotherapy be abandoned since there were no positive aspirates in 36,000 immunotherapy injections given at his practice $^{45}$. While other specialists agreed that aspiration prior to immunotherapy injection in SC tissue is very rarely positive, rare anecdotes were quoted when positive aspiration has been documented ${ }^{46,47}$, even in the hands of experienced specialists and nurses. Given the potentially fatal adverse reactions of immunotherapy injected into blood vessels, it is logical to recommend that aspiration be performed as part of the standard technique. However, fatal and near fatal adverse reactions have been reported following immunotherapy injection despite precautions, including aspiration, being taken ${ }^{45}$.

Epinephrine. Epinephrine is given through the SC or IM route to treat allergic reactions. Geller ${ }^{48}$ has reported the observation of a positive aspiration prior to epinephrine injection for asthma; if aspiration had not been performed in that instance, epinephrine would have been injected into the blood vessel with potentially hazardous consequences. On the other hand, the preloaded auto injector commonly used for administering epinephrine in emergency situations does not allow for aspiration $^{49}$. In this form, epinephrine is designed to be administered via IV injection, via intracardiac injection or via the endotracheal route into the bronchial tree where aspiration is superfluous.

Insulin. The NMC guidelines ${ }^{50,51}$ do not mention aspiration in relation to insulin injection. Aspiration prior to insulin injection is rarely positive ${ }^{36}$ and hence not indicated. This recommendation is supported by drawing a parallel with heparin administration, where increased hematoma formation has been associated with aspiration ${ }^{4}$. 
Dental procedures. A study looking at dental anesthetic injections showed positive aspiration rates ranging from 3.2-8\% depending on the type of syringe system used ${ }^{52}$ and the type of nerve block. Accuracy of needle position combined with mechanical ease at the time of dental injections are important considerations when choosing an appropriate device ${ }^{53}$. To this end, different self-aspirating devices have been tested in dental practice ${ }^{54}$. An understanding of vascular anatomy ${ }^{57}$ is all the more important in view of the potential toxicity of anesthetic agents and the possibility of embolization to the ophthalmic artery ${ }^{58}$.

The US CDC screening form ${ }^{55}$ for device specifics notes whether a dental syringe is capable of aspiration.

Immunization. Vaccinations form an important subset of all injections given worldwide. Most government programs worldwide follow UNICEF/WHO recommendation in their Expanded Program on Immunization (EPI) programs. At present, the WHO does not recommend aspiration prior to administering a vaccine ${ }^{7,56}$. Current guidelines published by the American Academy of Pediatrics $(\mathrm{AAP})^{57}$ recommend that aspiration prior to IM vaccinations may not be necessary, while similar Canadian guidelines continue to recommend aspiration ${ }^{58}$. The US Advisory Committee on Immunization Practices (ACIP) ${ }^{59}$ does not make any recommendations on aspiration at the time of vaccine administration. Without data indicating the need for aspiration during vaccination, ACIP is basically leaving this decision to the person giving the vaccine. A similar stance is taken by the US Immunization Action Coalition guideline ${ }^{40}$ where aspiration is not mentioned in its recommendations for SC and IM injections in adults, and it states that there are "no data to document the necessity of aspiration" in children.

A different approach to this issue was taken by Ipp et al. ${ }^{2}$ through a survey where the actual practice of end users was evaluated. This survey established that $74 \%$ of respondents aspirated prior to IM vaccine administration. However, of these only $3 \%$ aspirated for the recommended 5-10 seconds; the remaining applied negative pressure for $<5$ seconds. The same group went on to conduct a randomized controlled trial in which they compared two injection techniques: the standard approach, which included aspiration for 5-10 seconds, and the pragmatic approach, which excluded aspiration entirely $^{50}$. They concluded that IM vaccinations using the pragmatic approach were less painful and there were no benefits to following the standard approach. Jablecki ${ }^{60}$ has suggested a technique for choosing a site for administering IM injection that is relatively pain free by understanding the anatomy of cutaneous innervation at the selected site. This may mitigate the effect of increased pain in the standard approach. Similarly, Philippe Duclos, WHO/Vaccines and Biologicals, has recommended against aspiration prior to injection with a view to minimizing pain ${ }^{61}$. More recently, a 2007 study of 113 infant vaccinations compared rapid IM injection without aspiration with slow IM injection with aspiration, and found the non-aspiration method to be associated with less pain based on behavioral pain ratings ${ }^{41,62}$. Similarly, in 2009, a systematic review of 19 randomized controlled trials involving 2,814 infants and children found that immunization pain can be decreased by performing a rapid IM injection without aspiration ${ }^{41}$.
In actual practice, $\mathrm{AD}$ syringes are recommended worldwide for vaccinations. While this is a small proportion of all injections given worldwide, it is an important component given that the target population is healthy children, and the risks have to be minimized as much as possible. In general, AD syringes do not permit health workers to aspirate for blood. This inability to aspirate with AD syringes has generated a heated debate. In theory, some devices like the BD Soloshot allow for limited aspiration ${ }^{63}$, but this does not meet the recommended criteria for the amount of negative pressure and duration of aspiration.

A summary of the rationale behind the current recommendation of not aspirating during the administration of IM or SC vaccines is given below.

1. Recommended sites for immunizations do not have major blood vessels; hence the risk of accidentally injecting the vaccine into a blood vessel is thought to be minimal ${ }^{63}$.

2. AD syringes have been used in mass campaigns for IM injections without any reported adverse effects ${ }^{7,63}$ or injury from failure to aspirate ${ }^{7,64,65}$. All complications reported in the literature of intra-arterial injection involved penicillin and other medications and not vaccines ${ }^{1}$. "It is safe to assume that immunization as a class of IM injection poses less risk to the patient" than other medications, particularly antibiotics ${ }^{1,7,66,67}$. Hence, according to Clements ${ }^{7}$, "the practice of aspiration during vaccinations is not evidencebased".

3. Aspiration can result in wastage of vaccine ${ }^{64}$.

4. Aspiration prolongs the time that the needle is inside the patient hence increasing the pain experienced by the recipient ${ }^{50}$.

5. Less control is exercised during two-handed aspiration using a conventional syringe, which may lead to local injury. During a one handed vaccination without aspiration, the vaccinator can use the other hand to control the child ${ }^{7}$.

6. At present, at the public health level, the use of $\mathrm{AD}$ syringes represents best practice to protect the health of the public despite the fact $\mathrm{AD}$ syringes do not allow aspiration for the recommended 5-10 seconds. The increased risk presented by eliminating aspiration from routine vaccine administration technique can be mitigated to an extent by a thorough understanding of the anatomy and landmarks of recommended injection sites ${ }^{66}$.

The WHO appreciates that there is not enough evidence to support the exclusion of aspiration ${ }^{1,7}$ at present. As a result, "WHO is neither able to support nor offer alternative actions in relation to aspiration undertaken during the administration of vaccines. Until such time as clear evidence becomes available to indicate which method is preferable, vaccinators should make locally appropriate choices ${ }^{7}$ ". In addition, it is suggested that in individual clinical practice using non-AD syringes, aspiration should 
continue to be a part of the standard technique for IM injection administration $^{66}$.

The realization that the information available to the WHO may not be comprehensive is reflected in disclaimers that are incorporated in WHO documents/publications. The joint statement on AD syringes in immunization says, "The World Health Organization does not warrant that the information contained in this publication is complete and correct and shall not be liable for any damages incurred as a result of its use". All WHO publications state, "All reasonable precautions have been taken by the World Health Organization to verify the information contained in this publication. However, the published material is being distributed without warranty of any kind, either expressed or implied. The responsibility for the interpretation and use of the material lies with the reader. In no event shall the World Health Organization be liable for damages arising from its use. The named authors alone are responsible for the views expressed in this publication".

Special areas. The conventional syringe, primarily designed for injection, is widely used for aspiration. Sibbit et al. ${ }^{68}$ have found the conventional syringe to be unsuited for aspiration during FineNeedle Aspiration Cytology (FNAC). Robinson et al. ${ }^{69}$ reported a similar experience using conventional syringes for amniocentesis. Aspiration was found to be unreliable in reducing the risk of IV penetration during intraforaminal cervical and lumbosacral epidural steroid injections ${ }^{36,70}$. Loss of control during joint aspirations

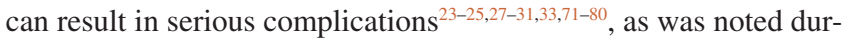
ing other invasive procedures like pericardiocentesis, amniocentesis and thoracocentesis ${ }^{77}$. Precision is important where critical organs are involved. Improved control was seen with the FDA-approved one-handed reciprocating syringe ${ }^{21}$.

\section{Findings of guidelines and recommendations}

Vaccination. According to the Red Book ${ }^{57}$ published by the American Academy of Pediatrics (AAP), there is no need of aspiration before injection of vaccines or toxoids. Similarly, the US CDC guidelines for administration of vaccines ${ }^{65}$ have clear instructions not to aspirate before injection (for both IM and SC routes), as no large vessels exist in the recommended injection site. No recommendations were found in the Pink Book ${ }^{81}$ from the CDC in this regard.

None of the documents dealing with immunization (including immunization in practice module 1-11 from the WHO) suggest that aspiration is required before injection of a vaccine ${ }^{82}$. The WHO Fact Sheet No 231 on Injection Safety, revised in October $2006^{83}$, focuses primarily on injection safety. Technical details, including aspiration, are not touched upon in this document.

Injection of medication. The UK NHS ${ }^{84}$ and Public Health Agency Canada $^{6}$ recommend aspiration before IM injection of medication.

Neither the ICN nor the Nursing and Midwifery Council ${ }^{50,51}$ (Europe and British Chapters) have made any kind of recommendation in their guidelines on administration of medication. The official website of the WHO's Uppsala Monitoring Center (UMC) ${ }^{85}$ does not list any warnings related to aspiration.
National nursing curricula in Nigeria ${ }^{86}$ and Pakistan ${ }^{87}$ do not mention aspiration before injection as a necessary step for IM and SC injections. Similarly the syllabus for MSc Nursing in India does not elaborated on injection technique. Curricula for primary health workers in Nigeria ${ }^{40}$ and nursing students in Pakistan's foremost nursing school (Aga Khan University School of Nursing) do advocate aspiration ${ }^{38}$ before injection. Similarly, the IndiaCLEN Model Injection Center Program advises aspiration prior to IM injection ${ }^{88}$. None of the curricula mentioned above make any comment on the duration of aspiration.

The United States Pharmacopeia-National Formulary ${ }^{89}$, British National Formulary ${ }^{90}$ and Pakistan Pharma Guide ${ }^{91}$ make no mention of aspiration before injection.

\section{Review of ISO guidelines}

The ISO recommendations 7886 for sterile hypodermic syringes (acquired via personal communication) were reviewed. Relevant sections from parts 1, 3 and 4 are reproduced below. Part 2 relates to syringes for use with power-driven pumps and is therefore beyond the scope of this review.

Part 1: Sterile hypodermic syringes for single use - specifies requirements for sterile single-use hypodermic syringes made of plastic materials and intended for the aspiration of fluids or for the injection of fluids immediately after filling.

Part 3: Auto-disable syringes for fixed dose immunization - specifies the properties and performance of sterile single-use hypodermic syringes, with or without needle, made of plastic materials and stainless steel and intended for the aspiration of vaccines or for the injection of vaccines immediately after filling. Upon delivering a fixed dose of vaccine, the syringe is automatically rendered unusable.

Part 4: Syringes with re-use prevention feature - specifies requirements for sterile single-use hypodermic syringes made of plastic materials with or without needle, and intended for the aspiration of fluids or for the injection of fluids immediately after filling and of design such that the syringe can be rendered unusable after use.

ISO Section 5.3: Intended use/application. The intended use/ application shall be categorized as follows:

Type A: single aspiration and injection.

Type B: multiple plunger aspirations prior to the final intended single use.

The term aspiration used in these guidelines indicates the drawing up of the vaccine or medication into the syringe prior to aspiration. Aspiration as defined in the context of this review is not directly referred to in these guidelines. It appears that withdrawal of the plunger for blood to be visible in the syringe if the needle tip is placed in a vessel, and for this function to be possible at any position of the piston within the graduated range, was considered for inclusion in the ISO guidelines at some point ${ }^{92}$. However, this is not included in ISO 7886 at all. 
Findings from product inserts

Product inserts for injectable drugs on the Essential Drug List were obtained from over 20 pharmacies across the city of Karachi, Pakistan $^{93}$

Each insert was checked and the level of evidence available was categorized as follows:

1. Clearly mentioned on the leaflet to aspirate before injection

2. No mention of aspiration on the leaflet, but advocates a particular route of administration because of the dangers of side effects
3. Suggests to stick to a particular route regardless of outcome of aspiration before injection

Only 3 drugs out of a total of 108 studied had level 1 evidence (bupivicaine, lidocaine and Pneumococcal 7-valent conjugate vaccine). Level-3 evidence was available for only 1 drug (Dactinomycin). The remaining essential drugs gave level-2 evidence Table 2.

\section{Discussion}

Aspiration prior to injection is just one part of the process of performing vaccinations, therapeutic injections and diagnostic/therapeutic procedures. The debate over its inclusion as an essential part of recommended techniques has driven this review, and is likely

Table 2. Summary of results based on information given in product inserts.

\begin{tabular}{|c|c|c|c|}
\hline Generic Name & Trade Name & $\begin{array}{l}\text { Level of } \\
\text { Evidence }\end{array}$ & Statement from the leaflet \\
\hline Dactinomycin & Cosmegen & 3 & $\begin{array}{l}\text { On intravenous administration of Cosmegen, extravasation } \\
\text { may occur with or without an accompanying burning or } \\
\text { stinging sensation, even if blood returns well on aspiration } \\
\text { of the infusion needle. If any signs or symptoms of } \\
\text { extravasation have occurred, the injection or infusion should } \\
\text { be immediately terminated and restarted in another vein. }\end{array}$ \\
\hline $\begin{array}{l}\text { Dephtheria, Pertusis, } \\
\text { Tetnus (DPT) }\end{array}$ & Infanrix & 2 & $\begin{array}{l}\text { Do not administer this product subcutaneously or } \\
\text { intravenously. }\end{array}$ \\
\hline $\begin{array}{l}\text { Tetanus toxoid, reduced } \\
\text { diphtheria toxoid and } \\
\text { acellular pertussis } \\
\text { vaccine }\end{array}$ & Boostrix & 2 & $\begin{array}{l}\text { Special care should be taken to prevent injection into a } \\
\text { blood vessel. }\end{array}$ \\
\hline Dacarbazine & DTIC-Dome & 2 & $\begin{array}{l}\text { The calculated dose of the resulting solution is drawn into } \\
\text { a syringe and administered only intravenously. }\end{array}$ \\
\hline Erythromycin lactobionate & Erythrocin & 2 & $\begin{array}{l}\text { Must be administered by continuous or intermittent } \\
\text { intravenous infusion only. } \\
\text { Due to the irritative properties of erythromycin, I.V. push is } \\
\text { an unacceptable route of administration. }\end{array}$ \\
\hline Hep B vaccine & Engerix-B & 2 & Do not inject intravenously or intradermally. \\
\hline MMR & Priorix Vaccine & 2 & $\begin{array}{l}\text { Your doctor/nurse will ensure that Priorix is not injected } \\
\text { into the bloodstream. }\end{array}$ \\
\hline Promethazine $\mathrm{HCL}$ & Phenergon & 2 & $\begin{array}{l}\text { The preferred route of administration for phenergan } \\
\text { injection is by deep IM injection. The proper IV } \\
\text { administration of the product is well tolerated, but use } \\
\text { of this route is not without some hazards. Not for SC } \\
\text { administration. }\end{array}$ \\
\hline $\begin{array}{l}\text { Pneumococcal } 7 \text {-valent } \\
\text { conjugate Vaccine }\end{array}$ & Prevnar & 1 & $\begin{array}{l}\text { For intramuscular injection only. Do not inject } \\
\text { intravenously. } \\
\text { After insertion of the needle, aspirate and wait to see if } \\
\text { any blood appears in the syringe, which will help avoid } \\
\text { inadvertent injection into a vessel. If blood appears, } \\
\text { withdraw the needle and prepare for injection at another } \\
\text { site. }\end{array}$ \\
\hline Progesterone injection & Progesterone & 2 & For intramuscular use only. \\
\hline Flupenthixol & Fluanxol & 2 & $\begin{array}{l}\text { Flupenthixol is administered by deep i.m. injection, } \\
\text { preferably in the gluteus maximus. Flupenthixol is NOT for } \\
\text { i.v. use. }\end{array}$ \\
\hline $\begin{array}{l}\text { Immune globulin } \\
\text { (Human), I.V. }\end{array}$ & Gamimune ${ }^{\circledR}$ & 2 & For intramuscular use only. \\
\hline
\end{tabular}




\begin{tabular}{|c|c|c|c|}
\hline Generic Name & Trade Name & $\begin{array}{l}\text { Level of } \\
\text { Evidence }\end{array}$ & Statement from the leaflet \\
\hline Bupivacaine $\mathrm{HCl}$ & Sensorcaine & 1 & $\begin{array}{l}\text { It is essential that aspiration for blood or cerebrospinal fluid } \\
\text { (where applicable) be done prior to injecting any local } \\
\text { anesthetic, both the original dose and all subsequent } \\
\text { doses, to avoid intravascular or subarachnoid injection. } \\
\text { However, a negative aspiration does not ensure against an } \\
\text { intravascular or subarachnoid injection. }\end{array}$ \\
\hline Thiopental Sodium & Pentothal & 2 & $\begin{array}{l}\text { The drug is prepared as a sterile powder and after } \\
\text { reconstitution with an appropriate diluent is administered } \\
\text { by the intravenous route. } \\
\text { Pentothal is administered by the intravenous route only. }\end{array}$ \\
\hline Diazepam & Valium Injection & 2 & $\begin{array}{l}\text { For dosage in pediatric patients > } 30 \text { days old, see the } \\
\text { specific indications below. When intravenous use is } \\
\text { indicated, facilities for respiratory assistance should be } \\
\text { readily available. } \\
\text { Intramuscular: Valium Injection should be injected deeply } \\
\text { into the muscle. } \\
\text { Intravenous Use: (See warnings and precautions: } \\
\text { Pediatric Use.) The solution should be injected slowly, } \\
\text { taking at least } 1 \text { minute for each } 5 \mathrm{mg}(1 \mathrm{~mL}) \text { given. Do } \\
\text { not use small veins, such as those on the dorsum of the } \\
\text { hand or wrist. Care should be taken to avoid intraarterial } \\
\text { administration or extravasation. }\end{array}$ \\
\hline $\begin{array}{l}\text { Typhoid Vi } \\
\text { Polysaccharide vaccine } \\
\text { Typhim Vi }\end{array}$ & Typhim & 2 & For intramuscular use only. Do NOT inject intravenously. \\
\hline $\begin{array}{l}\text { Purified inactivated rabies } \\
\text { vaccine }\end{array}$ & Verorab & 2 & Do not inject intravascularly. \\
\hline Lidocaine & Xylocaine & $1 \& 3$ & $\begin{array}{l}\text { It is essential that aspiration for blood or cerebrospinal } \\
\text { fluid (where applicable) be done prior to injecting any } \\
\text { local anesthetics, both the original and all subsequent } \\
\text { doses, to avoid intravascular or subarachnoid injection. } \\
\text { However, a negative aspiration does not ensure against an } \\
\text { intravascular or subarachnoid injection. Local anesthetic } \\
\text { solutions containing antimicrobial preservatives (e.g. } \\
\text { methylparaben) should not be used for epidural or spinal } \\
\text { anesthesia because the safety of these agents has not } \\
\text { been established with regard to intrathecal injection, either } \\
\text { intentional or accidental. }\end{array}$ \\
\hline $\begin{array}{l}\text { Rho (D) Immunoglobin } \\
\text { (Human) }\end{array}$ & $\mathrm{RHO}$ & 2 & Do not inject Intravenously. Do not inject neonate. \\
\hline
\end{tabular}

to continue in the absence of findings from randomized controlled trials. In most instances, general clinical or vaccination experiences guide global recommendations for aspiration. In others, anecdotal reports of adverse events form the basis for inclusion or exclusion of aspiration in standard injection techniques. The sheer number of injections given globally in the preventive and therapeutic sectors makes this omission even more surprising. This appraisal of current guidelines and literature has made it clear that the need for aspiration prior to administering an injection is dependent upon multiple factors, as elaborated below.

Injections given for the purpose of routine immunizations are different from injections for medications. The minimal risk of side effects combined with defined sites for immunization form one basis of the existing recommendations for eliminating aspiration during immunization. The fact that most AD devices currently in use do not allow for aspiration also appears to have been a major factor in the decision to eliminate aspiration as an essential step prior to IM or SC injection of vaccines. We argue that clinical needs should dictate the development of new devices and not the other way around. Relevant recommendations must be evidence-based and ISO guidelines must be modified to reflect evolving needs. This would drive the device industry to meet the criteria laid down based on scientific rationale.

The drug that is being injected has a direct bearing on the decision to aspirate or not to aspirate. If the drugs to be given have potentially fatal consequences in the event of systemic administration (as in the case of immunotherapy), all possible precautions must be taken. This is all the more important in cases where the drug is being administered electively by specialist staff. On the other hand, if there are no serious known sequelae to a drug being injected systemically - as in the case of vaccines - an argument can be made not to aspirate, especially since a huge number of immunizations 
are performed globally by vaccinators and health workers. Product inserts for 104 injectables on the WHO Essential Drug List were reviewed. Of these, only 3 inserts specified that aspiration should be performed prior to injection. Two of these inserts were for local anesthetic agents and the third was for Pneumococcal 7 -valent conjugate vaccine. Other product inserts mentioned the importance of injecting into the desired site, but did not specify aspiration as a way of ensuring this. Clearer instructions must be stated if indeed potentially serious complications may occur if a drug or vaccine is inadvertently administered at a site other than that recommended.

As is apparent from ISO 7886 part 4 for curative injection devices, a global shift towards the increasing the use of re-use prevention syringes in the curative sector is imminent. Devices manufactured to meet these criteria incorporate the function of aspiration. Newer devices are coming into the market in order to address the issues of control over the syringe during aspiration and to increase patient safety. One such device recently approved by the US Food and Drug Agency (FDA) is the highly controllable one handed reciprocating procedure syringe ${ }^{21}$. Specific procedures where aspiration is performed for diagnostic or therapeutic purposes would benefit from newer devices that are custom-designed to aspirate rather than inject.

A systematic approach would be to conduct randomized controlled trials of the device to reach an unbiased conclusion on the benefits and necessity for aspiration using therapeutic re-use prevention syringes and $\mathrm{AD}$ syringes for vaccinations; the appropriate duration of aspiration that yields best results also needs to be determined. If such trials deem that aspiration should be part of the recommended therapeutic and vaccination technique, this would act as the driving force for the device industry to develop appropriate tools to meet these requirements.

\section{Literature search terms}

"Aspiration", "injection", "technique", "procedure", "guidelines", "standards", "efficacy", "complications", "pain”, "trauma", "administration", "intramuscular", "intravascular", "intradermal", "subcutaneous", "syringe", "auto-disable syringe", "Z-track", "immunotherapy”, "epinephrine", "insulin”, "dental”, "immunization", "vaccination”, "medication", "rapid", "fine-needle", "pain", "trauma".

\section{Author contributions}

L Samad: Primary author, contributed to literature search and overall supervision. YJ Sepah: Literature review, collation and draft of results and report. A Altaf: Contributed to literature review. AJ Khan: Provided overall supervision and final review of manuscript.

\section{Competing interests}

No competing interests were disclosed.

\section{Grant information}

This literature review was funded by Star Syringe Ltd UK. All decisions regarding the content of the manuscript and final responsibility for submission of the manuscript belong to the authors.
1. Kamlesh RL, Lala MK: Intramuscular Injection: review and guidelines. Indian Pediatr. 2003; 40(9): 835-845. PubMed Abstract

2. Ipp M, Sam J, Patricia PC: Needle aspiration and intramuscular vaccination. Arch Pediatr Adolesc Med. 2006; 160(4): 451. PubMed Abstract | Publisher Full Text

3. Mallet J, Christopher B: The Royal Marsden NHS Trust Manual of Clinical Nursing Procedure. 4th ed. London: Blackwell Science. 1996. Reference Source

4. Workman B: Safe injection techniques. Nurs Stand. 1999; 13(39): 47-53. PubMed Abstract | Publisher Full Text

5. Crawford $\mathrm{CL}$, Johnson JA: To aspirate or not: an integrative review of the evidence. Nursing. 2012; 42(3): 20-5. PubMed Abstract | Publisher Full Text

6. Canada, PHAo, Canadian Immunization Guide. 7th ed. Ottawa. Publishing and Depository Services Public Works and Government Services Canada: Ontario. 2006. Reference Source

7. J CC: Aspiration before injection, in SIGN. 2003; 1-2.

8. Aceves-Avila FJ, Delgadillo-Ruano M, Ramos-Remus C, et al.: The first descriptions of therapeutic arthrocentesis: a historical note. Rheumatology (Oxford). 2003; 42(1): 180-3. PubMed Abstract | Publisher Full Text

9. Guggi V, Calame L, Gerster JC: Contribution of digit joint aspiration to the diagnosis of rheumatic diseases. Joint Bone Spine. 2002; 69(1): 58-61. PubMed Abstract | Publisher Full Text

10. Lane JG, Falahee M, Wojtys EM, et al:: Pyarthrosis of the knee. Treatment considerations. Clin Orthop Rel Res. 1990; 45(252): 198-204. PubMed Abstract
11. Johnson MW: Acute knee effusions: a systematic approach to diagnosis. Am Fam Physician. 2000; 61(8): 2391-400. PubMed Abstract

12. Manadan AM, Block JA: Daily needle aspiration versus surgical lavage for the treatment of bacterial septic arthritis in adults. Am J Ther. 2004; 11(5): 412-5. PubMed Abstract | Publisher Full Text

13. Dooley P, Martin R: Corticosteroid injections and arthrocentesis. Can Fam Physician. 2002; 48: 285-92. PubMed Abstract | Free Full Text

14. Brown PW: Arthrocentesis for diagnosis and therapy. Surg Clin North Am. 1969; 49(6): 1269-78. PubMed Abstract

15. Lee $A H$, Chin $A E$, Ramanujam T, et al.: Gonococcal septic arthritis of the hip. J Rheumatol. 1991; 18(12): 1932-3. PubMed Abstract

16. Kesteris $\mathrm{U}$, Wingstrand $\mathrm{H}$, Forsberg $\mathrm{L}$, et al:: The effect of arthrocentesis in transient synovitis of the hip in the child: a longitudinal sonographic study. $J$ Pediatr Orthop. 1996; 16(1): 24-9. PubMed Abstract | Publisher Full Text

17. Weidner $\mathrm{S}$, Keller $\mathrm{W}$, Kellner $\mathrm{H}$ : Interventional radiology and the musculoskeletal system. Best Pract Res Clin Rheumatol. 2004; 18(6): 945-56. PubMed Abstract | Publisher Full Text

18. Bureau NJ, Ali S, Chhem RK, et al:: Ultrasound of musculoskeletal infections. Semin Musculoskelet Radiol. 1998; 2(3): 299-306. PubMed Abstract | Publisher Full Text

19. Grassi W, Farina A, Filippucci E, et al:: Sonographically guided procedures in rheumatology. Semin Arthritis Rheum. 2001; 30(5): 347-53. PubMed Abstract | Publisher Full Text 
20. Feldmann $\mathrm{H}$ : [2000-year history of the ear syringe and its relationship to the enema. Images from the history of otorhinolaryngology, represented by instruments from the collection of the Ingolstadt Medical History Museum] Laryngorhinootologie. 1999; 78(8): 462-7.

PubMed Abstract | Publisher Full Text

21. Sibbitt W Jr, Sibbitt RR, Michael AA, et al.: Physician control of needle and syringe during aspiration-injection procedures with the new reciprocating syringe. J Rheumatol. 2006; 33(4): 771-78. PubMed Abstract

22. Draeger HT, Twining JM, Jhonson CR, et al.: A randomised controlled trial of the reciprocating syringe in arthrocentesis. Ann Rheum Dis. 2006; 65(8): 1084-7. PubMed Abstract | Publisher Full Text | Free Full Text

23. Roberts WN, Hayes CW, Breitbach SA, et al:: Dry taps and what to do about them: a pictorial essay on failed arthrocentesis of the knee. Am J Med. 1996; 100(4): 461-4.

PubMed Abstract | Publisher Full Text

24. Lobo A, Lightman S: Vitreous aspiration needle tap in the diagnosis of intraocular inflammation. Ophthalmology. 2003; 110(3): 595-9. PubMed Abstract | Publisher Full Text

25. Qublan HS, Al-Jader K, Al-Kaisi NS: Fine needle aspiration cytology compared with open biopsy histology for the diagnosis of azoospermia. $J$ Obstet Gynaecol. 2002; 22(5): 527-31.

PubMed Abstract | Publisher Full Text

26. Jauniaux $\mathrm{E}$, Holmas $\mathrm{A}$, Hyett $\mathrm{J}$, et al.: Rapid and radical amniodrainage in the treatment of severe twin-twin transfusion syndrome. Prenat Diagn. 2001; 21(6) 471-6.

PubMed Abstract | Publisher Full Text

27. Cederholm M, Haglund B, Axelsson O: Maternal complications following amniocentesis and chorionic villus sampling for prenatal karyotyping. BJOG. 2003; 110(4): 392-9. PubMed Abstract | Publisher Full Text

28. Farran I, Sánchez M, Mediano C, et al:: Early amniocentesis with the filtration technique: neonatal outcome in 123 singleton pregnancies. Prenat Diagn. 2002; 22(10): 859-63.

PubMed Abstract | Publisher Full Text

29. Papp C, Papp Z: Chorionic villus sampling and amniocentesis: what are the risks in current practice? Curr Opin Obstet Gynecol. 2003; 15(2): 159-65. PubMed Abstract

30. Moore KP, Wong F, Gines $\mathrm{P}$ et al.: The management of ascites in cirrhosis: report on the consensus conference of the International Ascites Club Hepatology. 2003; 38(1): 258-66.

PubMed Abstract | Publisher Full Text

31. Murthy SV, Hussain ST, Gupta S, et al:: Pseudoaneurysm of inferior epigastric artery following abdominal paracentesis. Indian J Gastroenterol. 2002; 21(5): 197-8. PubMed Abstract

32. Webster ST, Brown KL, Lucey MR, et al.: Hemorrhagic complications of large volume abdominal paracentesis. Am J Gastroenterol. 1996; 91(2): 366-8. PubMed Abstract

33. Nettleman MD, Bock MJ, Nelson AP, et al:: Impact of procedure-related complications on patient outcome on a general medicine service. $J$ Gen Intern Med. 1994; 9(2): 66-70. PubMed Abstract | Publisher Full Text

34. WHO, Global Facts \& Figures. A safe injection does not harm the recipient, does not expose the health care worker to any risk and does not result in waste that is dangerous for the community, in SAFETY OF INJECTIONS. 2006; 33: 4 .

35. Rodger MA, King L: Drawing up and administering intramuscular injections: a review of the literature. J Adv Nurs. 2000; 31(3): 574-582. PubMed Abstract | Publisher Full Text

36. Furman MB, Giovanniello MT, O'Brien EM: Incidence of intravascular penetration in transforaminal cervical epidural steroid injections. Spine (Phila Pa 1976). 2003; 28(1): 21-25.

PubMed Abstract

37. Higgins D: Subcutaneous Injections. Nursing times. 2004; 100(50): 32-3. PubMed Abstract

38. Rozani N: Aga Khan University School of Nursing enrichement program: Skills check list mannual, ed. AHN. Vol. 1. 2007, Karachi. 10.

39. Clinical Skills: Intramuscular Injections. Nursing times. 2003; 99(26): 27.

40. Nigeria C.h.p.r.b.o: Practical assesment record for cummunity health extension workers. Instructors Guide Book. 2006.

41. Taddio A, et al:: Physical interventions and injection techniques for reducing injection pain during routine childhood immunizations: systematic review of randomized controlled trials and quasi-randomized controlled trials. Clin Ther. 2009; 31(Suppl 2): S48-76.

PubMed Abstract | Publisher Full Text

42. Hayes C: Injection technique subcutaneous. Nursing times. 1998; 94(41): suppl 1-2. PubMed Abstract

43. WHO, I SIGN. Best Infection Control Practices for Skin-Piercing Intradermal, Subcutaneous, and Intramuscular Needle Injections. 2001; [cited 2008 June 23] Reference Source

44. WHO. A guide for supervising injections. Feb 2004 April 2008 [cited 2013 March 15]; Feb 12. 2004: [1-16]

Reference Source
45. Waibel $\mathrm{KH}$ : Aspiration before immunotherapy injection is not required. J Allergy Clin Immunol. 2006; 118(2): 525-6.

PubMed Abstract | Publisher Full Text

46. Miller JD, Bell JB, Lee RJ, et al.: Blood return on aspiration before immunotherapy injection. J Allergy Clin Immunol. 2006; 119(2): 512. PubMed Abstract | Publisher Full Text

47. Guarneri F: Aspiration before subcutaneous immunotherapy injection: Unnecessary or advisable? J Allergy Clin Immunol. 2007; 119(2): 512-513. PubMed Abstract | Publisher Full Text

48. Geller M: Aspiration before immunotherapy injection is required. $J$ Allergy Clin Immunol. 2007; 120(1): 220-1.

PubMed Abstract | Publisher Full Text

49. H WK: Reply: Letter to the editor. J Allergy Clin Immunol. 2006; 120(1).

50. Council NM: Guidelines for the administration of medicine. 2002. [cited 2014 March 15].

Reference Source

51. Council NM: Standards for medicines management. 2004. [cited 2014 March 15] Reference Source

52. Corkery PF, Barrett BE: Aspiration using local anesthetic catridges with an elastic recoil diaphragm. J Dent. 1973; 2(2): 72-74.

PubMed Abstract | Publisher Full Text

53. Meechana JG, Ramacciato JC, McCabea JF: A comparison of the aspirating abilities of re-usable and partly disposable dental cartridge syringes in vitro. J Dent. 2006; 34(1): 41-47.

PubMed Abstract | Publisher Full Text

54. Petersen JK: Efficacy of a self-aspirating syringe. Int J Oral Maxillofac Surg. 1987; 16(2): 241-4

PubMed Abstract | Publisher Full Text

55. Control, C.o.D. Sample Screening Form Dental Safety Syringes and Needles. 2002. [cited 2014 March 15].

56. Calin MA, Parasca SV, Savastru R, et al:: Optical techniques for the noninvasive diagnosis of skin cancer. J Cancer Res Clin Oncol. 2013; 139(7): 1083-104. PubMed Abstract | Publisher Full Text

57. Pickering LK, EG V: III. Active and Passive Immunization: Report of the Committee on Infectious Diseases. 26th ed. Red book. 2003: American Academy of Pediatrics. Reference Source

58. Immunization, N.A.C.o., Canadian Immunization Guide. H. Canada, Editor. 2002, Public Health Agency of Canada, Infectious Disease and Emergency Preparedness Branch, Centre for Infectious Disease Prevention and Control: Ontario. 38-40. Branch, Centre for I
Reference Source

59. CDC. Vaccine Administration. In: General recommendations on Immunisation Eds. William LA, L.P., Benjamin S, Bruce W, John Iskander, John Watson, Atlanta, USA. MMWR. 2002; 51(RR02): 1-36.

Reference Source

60. Jablecki CK: Letter to the Editor. Nursing Res. 2000; 49(5): 244. Reference Source

61. Duclos P: WHO/V\&B. SIGN January 2003 July 2008 [cited 2014 March 15]. 1-2.

62. Ipp M, Taddio A, Sam J, et al.: Vaccine-related pain: randomised controlled trial of two injection techniques. Arch Dis Child. 2007; 92(12): 1105-8. PubMed Abstract | Publisher Full Text | Free Full Text

63. Catlin M, Crook B: Giving safe injections: introducing auto-disable syringes. PATH Seattle, WA U.S.A. 2000.

Reference Source

64. Program NI: Epidemiology and Prevention of Vaccine-Preventable Diseases 2007; [cited 2014 March 15]

Reference Source

65. APPENDIX D. Vaccine Administration. 2007; [cited 2008 July 1] Reference Source

66. Nicoll LH: IM injection: updated information. SIGNpost September. 2002; 1-2. [cited 2014 March 15].

67. Nicoll LH, Hesby A: Intramuscular injection: an integrative research review and guideline for evidence-based practice. Appl Nurs Res. 2002; 15(3): 149-162. PubMed Abstract | Publisher Full Text

68. Sibbitt RR, Sibbitt WL Jr, Nunez SE, et al.: Control and performance characteristics of eight different suction biopsy devices. J Vasc Interv Radiol. 2006; 17(10): 1657-1669.

PubMed Abstract | Publisher Full Text

69. Robinson JN, Loeffler HH, Norwitz ER: A syringe adapter to facilitate aspiration at amniocentesis. Obstetrics \& Gynecology. 2000; 96(1): 138-140.

70. Furman MB, O'Brien EM, Zgleszewski TM: Incidence of intravascular penetration in transforaminal lumbosacral epidural steroid injections. Spine (Phila Pa 1976). 2000; 25(20): 2628-2632.

PubMed Abstract | Publisher Full Text

71. Yankelevitz DF, Hayt D, Henschke Cl: Transthorasic needle biopsy. What size syrine? Clin Imaging. 1995; 19(3): 208-209. PubMed Abstract | Publisher Full Text

72. Castellote $\mathrm{J}$, Xiol X, Cortés-Beut R, et al:: Complications of thoracentesis in cirrhotic patients with pleural effusion. Rev Esp Enferm Dig. 2001; 93(9): 566-75. PubMed Abstract

73. Doyle JJ, Hnatiuk OW, Torrington KG, et al.: Necessity of routine chest roentgenography after thoracentesis. Ann Intern Med. 1996; 124(9): 816-20. PubMed Abstract | Publisher Full Text 
74. Sassoon CS, Light RW, O'Hara VS, et al:: latrogenic pneumothorax: etiology and morbidity. Results of a Department of Veterans Affairs Cooperative Study. Respiration. 1992; 59(4): 215-20.

PubMed Abstract | Publisher Full Text

75. Callahan JA, Seward J: Pericardiocentesis Guided by Two-Dimensional Echocardiography. Echocardiography. 1997; 14(5): 497-504 PubMed Abstract | Publisher Full Text

76. Bastian A, Meissner A, Lins M, et al.: Pericardiocentesis: differential aspects of a common procedure. Intensive Care Med. 2000; 26(5): 572-6.

PubMed Abstract | Publisher Full Text

77. Salem K, Mulji A, Lonn E: Echocardiographically guided pericardiocentesis - the gold standard for the management of pericardial effusion and cardiac tamponade. Can J Cardiol. 1999; 15(11): 1251-5. PubMed Abstract

78. Tsang TS, Barnes ME, Gersh BJ, et al:: Outcomes of clinically significant idiopathic pericardial effusion requiring intervention. Am J Cardiol. 2003; 91(6): 704-7. PubMed Abstract | Publisher Full Text

79. Tsang TS, El-Najdawi EK, Seward JB, et al.: Percutaneous echocardiographically guided pericardiocentesis in pediatric patients: evaluation of safety and efficacy. J Am Soc Echocardiogr. 1998; 11(11): 1072-7. PubMed Abstract

80. Duvenoy OBJ, Borowiec J, Helmius G, et al.: Complications of percutaneous pericardiocentesis under fluoroscopic guidance. Acta Radiol. 1992; 33(4): 309-13. PubMed Abstract | Publisher Full Text

81. Atkinson W, Hamborsky J, Mclntyre L, et al.: The Pink Book. 10th ed. 2nd printing ed.Epidemiology and Prevention of Vaccine-Preventable Diseases. Washington DC: Public Health Foundation: Centers for Disease Control and Prevention. 2008. Reference Source

82. Kaic B: Aspiration before injection. SIGNpost January 2003 July 2008.

Reference Source
83. WHO. Fact sheet $\mathbf{N}^{\circ} \mathbf{2 3 1}$ Injection safety. 2002; [cited 2008 March 21]. Reference Source

84. NHS. Administration of medicines through intramuscular injections - Guidelines. 2006; [cited 2014 March 15] Reference Source

85. Center, T.U.M. Adverse reactions newsletter. 1996 Reference Source

86. Nigeria, C.h.p.r.b.o., Curriculum for higher diploma in cummunity health Instructors Guide Book. 2006.

87. Curriculum, P.N.C.B.N. 1990; 50-51.

88. IndiaCLEN. Model Injection Centres (MICs): A Program to Improve Injection Practices in the Country (2005-2006). Reference Source

89. Nguyen QD, Tatlipinar S, Shah SM, et al.: Vascular endothelial growth factor is a critical stimulus for diabetic macular edema. Am J Ophthalmol. 2006; 142(6): 961-9. PubMed Abstract | Publisher Full Text

90. British National Formulary. 2007; [cited 2014 March 15]. Reference Source

91. Pakistan Pharma Guide. [cited 2014 March 15]. Reference Source

92. Battersby A: "To aspirate or not to aspirate" that is the question. SIGN January 2003 July 2008 [cited 2014 March 15]; July 2008: [1-2]. Reference Source

93. Safety, C.o.I. Supplementary Material. 2009 [cited 2014 March 15] Reference Source 


\section{Open Peer Review}

\section{Current Peer Review Status:}

\section{Version 1}

Reviewer Report 30 December 2015

https://doi.org/10.5256/f1000research.1271.r11456

(C) 2015 Balani A et al. This is an open access peer review report distributed under the terms of the Creative Commons Attribution License, which permits unrestricted use, distribution, and reproduction in any medium, provided the original work is properly cited.

\section{Ankit Balani}

Department of Radiology, Yashoda Hospitals, Secunderabad, India

Sandhya Sarjare

Department of Radiology, Yashoda Hospital, Secunderabad, India

The manuscript is intelligently written and authors have provided a literature review of need of pre-injection aspiration and discussed its utility in clinical practice. However, we would like to make a few pertinent observations:

The authors have not concluded the review article and it would be appreciated if they could summarize their observations from the literature review and provide an appropriate conclusion giving the readers an insight into the necessity of pre-injection aspiration.

Grammatical error in abstract: medical/-nursing schools... needs to be replaced with medical/nursing.

Grammatical error in literature review (methodology) - first line - An literature review to be replaced by $\mathbf{A}$ literature review.

Grammatical error in Results - Immunization - Page 5: AD syringes do not permit health workers to aspirate for blood to be replaced to aspirate blood.

Grammatical error in Findings of guidelines and recommendation (injection of medication) - Page 6 - ..Msc Nursing in India does not elaborated on injection techniques needs to be replaced with did not elaborate injection techniques.

In review of ISO guidelines, ISO section 5.3 - Page 6 - ...vaccine or medication into the syringe prior to aspiration to be replaced by ....prior to injection.

Spelling errors in Table 2 including Diphtheria and Tetanus in second row need to be rectified. 
Competing Interests: No competing interests were disclosed.

We confirm that we have read this submission and believe that we have an appropriate level of expertise to confirm that it is of an acceptable scientific standard.

Reader Comment 17 Jan 2017

Yasir Sepah, Stanford University, USA

All the grammatical and spelling errors have been addressed as identified by the reviewer.

Competing Interests: None

Reviewer Report 04 September 2014

https://doi.org/10.5256/f1000research.1271.r5402

(C) 2014 Smit Sibinga C. This is an open access peer review report distributed under the terms of the Creative Commons Attribution License, which permits unrestricted use, distribution, and reproduction in any medium, provided the original work is properly cited.

\section{Cees Smit Sibinga}

IQM Consulting for International Development of Quality Management in Transfusion Medicine, Zuidhorn, The Netherlands

The authors have compiled important information based on both literature review and the analysis of guidelines and medication inserts on the issue of pre-injection aspiration once a needle is inserted in or under the skin.

However, the review might be improved by bringing in a more systematic approach in which the results follow the description in the Methodology. That would lead to a consistent and orderly review of the different aspects identified. It is also recommended to include in the introduction a definition of aspiration in the context of the review.

Table 2 shows several spelling errors that need to be corrected.

On page 6/11 (second column, last paragraph) the sentence '.... the drawing up of the vaccine or medication into the syringe prior to aspiration.' erroneously uses the word aspiration where this should be injection.

A clear conclusion with feasible recommendations to come to evidence pro or con, or at least a nuancing in the pro and con of pre-injection aspiration would certainly contribute, as this is not really expressed.

Competing Interests: No competing interests were disclosed. 
I confirm that I have read this submission and believe that I have an appropriate level of expertise to confirm that it is of an acceptable scientific standard, however I have significant reservations, as outlined above.

Reader Comment 17 Jan 2017

Yasir Sepah, Stanford University, USA

The errors identified by the reviewer have been addressed. A conclusion section has been added to the manuscript.

Competing Interests: None

The benefits of publishing with F1000Research:

- Your article is published within days, with no editorial bias

- You can publish traditional articles, null/negative results, case reports, data notes and more

- The peer review process is transparent and collaborative

- Your article is indexed in PubMed after passing peer review

- Dedicated customer support at every stage

For pre-submission enquiries, contact research@f1000.com 